


\title{
IMAGENS E DESENHOS INFANTIS NOS PROCESSOS DE CONSTRUCÃO DE SENTIDOS EM UMA SEQUÊNCIA DE ENSINO SOBRE CICLO DA ÁGUA
}

\author{
Andreza Fortinida Silva* \\ Orlando Aguiar Jr.** \\ Célia Abicalil Belmiro***
}

RESUMO: Este trabalho tem como objetivo investigar a linguagem dos desenhos das crianças e as contribuições de um infográfico animado sobre o ciclo da água como recurso mediacional no processo de construção de sentidos nas aulas de ciências. A pesquisa, de natureza qualitativa, se apoia em construtos teórico-metodológicos da perspectiva sócio-histórica e da semiótica social. A coleta dos dados da pesquisa aconteceu em uma turma do $3^{\circ}$ ano do Ensino Fundamental de uma escola pública do município de Contagem/MG. Para examinar a efetividade do desenho da criança como um modo de produção de sentidos na construção do conhecimento, buscamos investigar quais os indícios de compreensão sobre o ciclo da água podem ser observados nos desenhos produzidos pelas crianças em dois momentos da sequência de ensino: na primeira aula - levantamentos das ideias preliminares das crianças - e na quarta aula, após a utilização de um infográfico animado. Os resultados reforçam o potencial expressivo e comunicativo dos desenhos infantis na construção de conceitos científicos e sua relação com os textos verbais escritos. Além disso, os progressos no entendimento das crianças sobre o ciclo da água demonstram a efetividade do infográfico animado, apresentado pela professora com intensa participação dos estudantes, enquanto recurso mediacional.

Palavras-chave: desenho infantil, ensino de ciências, imagens, semiótica social.

\footnotetext{
IMÁGENES Y DIBUJOS INFANTILES EM LOS PROCESOS DE CONSTRUCCIÓN DE SENTIDOS EN UNA SECUENCIA DE ENSEÑANZA ACERCA DEL CICLO DEL AGUA

RESUMEN: Este trabajo tiene como objetivo investigar los dibujos de niños comprendidos como lenguaje y las contribuciones de una infografía animada como recurso de mediación en el proceso de construcción de sentidos en las clases de ciencias acerca del ciclo del agua. La investigación, de naturaleza cualitativa, se apoya en constructos teórico-metodológicos de la perspectiva socio-histórica y de la semiótica social. La recopilación de los datos de la investigación ocurrió en una clase del tercer año de la Primaria de una escuela pública en Contagem/ MG/Brasil. Para examinar la efectividad del dibujo de niños como un modo de producción de sentidos en la construcción del conocimiento, buscamos investigar cuales indicios de comprensión acerca del ciclo del
}

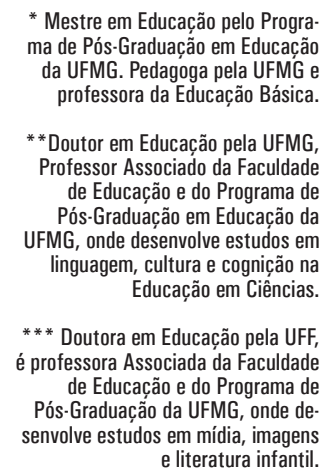
e literatura infantil. 
agua pueden ser observados en los dibujos producidos por los alumnos en dos momentos de la secuencia de enseñanza: en la primera clase recopilación de las ideas preliminares de los alumnos - y en la cuarta clase, después de la utilización de una infografía animada. Los resultados refuerzan el potencial expresivo y comunicativo de los dibujos infantiles en la construcción de conceptos científicos y su relación con los textos verbales escritos. Además, los progresos en la comprensión de los niños acerca del ciclo del agua demuestran la efectividad de la infografía animada presentada por la profesora, con intensa participación de los estudiantes, como recurso de mediación.

Palabras clave: Dibujo infantil. Enseñanza de las ciencias. Imágenes. Semiótica Social.

\section{IMAGES AND CHILDREN'S DRAWINGS IN A PROCESS OF MEANING CONSTRUCTIONON A TEACHING SEQUENCE ABOUT WATER CYCLE}

ABSTRACT: This work aims to investigate children's drawings understood as language and the contributions of an animated info-graphic as a mediational resource in the meaning making process in science classes on the water cycle. The research is based on theoretical and methodological constructs of socio-historical approach and social semiotics. Data were collected in a 3rd year class at a public school in the city of Contagem/ MG. To examine the effectiveness of the children's drawing as a way of production in knowledge construction, we seek to investigate what signs of understanding of the water cycle can be found in the drawings produced by children in two moments of the teaching sequence on water cycle: in the first class - drawing based on the preliminary ideas of children - and in the fourth class, after the use of an animated info-graphic. The results reinforce the expressive and communicative potential of children's drawings on the construction of scientific concepts and their relationship with written verbal texts. In addition, progress in children's understanding about the water cycle demonstrate the effectiveness of the animated infographic, presented by the teacher with intense participation of the students, as a mediacional mean.

Key words: children's drawing, science education, images, language and cognition. 


\section{INTRODUÇÃO}

Nos últimos anos, os estudos sobre as imagens no contexto escolar têm se desenvolvido, entre outras razões, pelo interesse de se compreender a importância atribuída a estes recursos semióticos no desenvolvimento cognitivo dos estudantes e nos processos de produção e compartilhamento de sentidos. No ambiente escolar, as imagens são utilizadas como um importante recurso didático em diferentes gêneros textuais e discursivos. Cartazes informativos, mapas, livros didáticos, propagandas, revistas, dvd's, pinturas, desenhos, vídeos, diagramas, gráficos e infográficos são alguns exemplos da utilização das imagens como recurso mediacional. Os professores recorrem ao trabalho com imagens para, entre outros objetivos: apresentar e discutir informações, estabelecer relações entre conteúdos escolares e suas aplicações na sociedade, estimular a imaginação e criatividade dos estudantes, dar suporte ao desenvolvimento de conceitos científicos.

Fora do ambiente escolar as crianças convivem em outros contextos que estão permeados de mensagens visuais, repletas de informações sígnicas verbais, gestuais, gráficas, icônicas, sonoras, entre outras. O processo de compreensão desses signos, convencionados em um contexto social e histórico, envolve interações complexas de produção de sentidos. Este é um dos motivos importantes para que sejam desenvolvidas, na escola - espaço privilegiado de formação e informação de crianças, jovens e adultos - habilidades de produção e leitura de imagens.

À luz da perspectiva histórico-cultural, o desenho é compreendido como um signo constituído por marcas culturais disponibilizadas ao sujeito através das interações sociais, que podem influenciar e modificar a estrutura de suas funções psicológicas. Conforme explica Ferreira (1998, p.47) o desenho é um produto da atividade humana que passa por várias transformações - desde o rabisco, o traçado, até figuras mais elaboradas - pode adquirir o caráter de instrumento simbólico. Nesse sentido, o desenho atua como mediador no desenvolvimento das funções psicológicas superiores, orientando o pensamento e a conduta da criança.

O propósito desta pesquisa foi o de examinar, em maior detalhe, as potencialidades do uso de imagens e desenhos infantis como recursos para produção e negociação de sentidos no contexto do ensino de ciências nos anos iniciais do Ensino Fundamental.

Iremos analisar o modo de compreensão das crianças sobre o ciclo da água, a partir dos seus próprios desenhos, das explicações orais apresentadas por eles e das produções de textos verbais escritos, realizadas em dois momentos da sequência de ensino. A primeira produção deu-se ao final da primeira aula da sequência de ensino, diante da pergunta “de onde vem a chuva?". Nesta primeira aula, a professora fez um levantamento de ideias preliminares dos estudantes relacionadas à palavra água para organizar toda a sequência de estudos sobre o tema. A segunda produção foi confeccionada na quarta aula da sequência de ensino, na semana posterior à utilização de um infográfico animado ${ }^{1}$ sobre o ciclo da água. A partir da análise dessa sequência, procuramos responder às seguintes questões: 1) 
Quais indícios de compreensão sobre o ciclo da água podem ser observados nos textos orais e escritos dos desenhos dos alunos?; 2) Quais são as possíveis contribuições do infográfico animado, utilizado pela professora como um dos recursos mediacionais, para a construção e o desenvolvimento dos significados relacionados ao conceito de ciclo da água?

\section{Marco teórico}

O desenho infantil, como objeto de estudo psicológico da criança, data da segunda metade do século XIX. De acordo com Iavelberg (2008), entre os séculos XIX e XX, vários pesquisadores se debruçaram sobre o desenho infantil, considerando a necessidade de um amadurecimento sensório-motor, cognitivo e sócio-afetivo da criança.

A influência de Vygotsky, na década de 1980, e suas formulações sobre o desenvolvimento do pensamento e da linguagem mediados por signos sócio-históricos, através das interações com o mundo e com os outros sujeitos, contribuíram para uma percepção mais ampla do desenho infantil. Este passa, então, a ser compreendido como uma força visual e cultural que traz marcas do contexto em que a criança vive e das relações que ela estabelece com informantes ou fontes de informação. Desde a infância, a criança, inserida em um contexto social, apreende o objeto semiótico a partir de suas formas de uso vivenciadas no grupo, incluindo as atividades cotidianas e escolares.

Pesquisas atuais no campo do ensino de ciências, influenciadas pela psicologia sócio-histórica, têm apresentado importantes contribuições aos estudos que privilegiam a integração e a orquestração de diferentes modos semióticos na comunicação em sala de aula e, em particular, para a análise das interações discursivas e das imagens como recurso mediacional no processo de ensino-aprendizagem no contexto das aulas de ciências.

Por sua importância para esta pesquisa, destacamos os trabalhos: de Souza e Gouvêa (2009) e Pralon (2011) que discutiram a utilização das imagens relacionadas ao tema da saúde nos livros didáticos de uma coleção voltada aos quatro últimos anos do Ensino Fundamental ( $6^{\circ}$ ao $9^{\circ}$ ano); de Martins e Gouvêa (2005) que investigaram como as imagens presentes nos livros didáticos de ciências são lidas e compreendidas por estudantes de oitavo ano do Ensino Fundamental; de Martins, Gouvêa e Piccinini (2005) que analisaram os diferentes papéis desempenhados pelas imagens nos livros didáticos de ciências, a leitura das imagens dos alunos do $3^{\circ}$ e $4^{\circ}$ ciclos do Ensino Fundamental e as formas de utilização das imagens desses livros em situações de ensino e por fim, o trabalho de Coutinho et al.(2010) que analisam o valor didático de imagens que compõem quatro coleções de livros de Biologia do Ensino Médio. Além desses, no trabalho de Carvalho e Barbosa-Lima (2008) os desenhos infantis são utilizados como instrumento de avaliação da construção do conhecimento físico e Schwarz et al (2007), consideram os desenhos infantis como um importante instrumento metodológico para avaliar conhecimentos, competências, observações e os conceitos de ciências das 
crianças sobre a Mata Atlântica e sua biodiversidade.

Nos trabalhos de Vygotsky (2003, 2007) o desenho é definido como uma forma de linguagem, assim como a escrita. Este autor também afirma que, na maioria das crianças, o desenho e a escrita se desenvolvem após a fala se tornar um hábito. Segundo ele, a imaginação atribuída ao desenho infantil assume um papel importante na ampliação do repertório da criança, estando diretamente relacionada às reconstruções de elementos visuais que pertencem ao mundo de referência, tomados de experiências anteriores. A criança se apropria desses elementos, internalizando-os em seu repertório psicológico e expressando no desenho as suas impressões. Através dessa linguagem específica, a criança organiza informações, processa experiências, exercita a imaginação, externaliza suas emoções, ressignifica a vida cotidiana e interpreta os objetos desenhados de um modo muito particular.

Para Vygotsky $(2003,2007)$ o desenho infantil, entendido como um modo de expressão da criança, típico da idade pré-escolar, passa por etapas de transformações semelhantes até o início da adolescência, quando é percebido um estacionamento em seu desenvolvimento. Segundo Iavelberg (2008), a orientação que o aluno recebe pode promover ou estagnar o processo criativo no uso da linguagem do desenho. Essa estagnação ou bloqueio criativo, embora seja claramente perceptível na adolescência entre os 12 e 14 anos, tem sido percebida também nas crianças da educação infantil e do primeiro ciclo do ensino fundamental. Segundo a autora, o receio e a insegurança das crianças pequenas em desenhar pode ser o resultado de uma exposição precoce e excessiva de imagens visuais, desprendida de um trabalho que oriente a leitura e estimule o desenvolvimento da criação pessoal e da beleza estética de um trabalho de autoria. Ou, ainda, por existir na escola uma insistência em ensinar um padrão "correto" de desenho para que a criança o reproduza fielmente.

Kress e Van Leeuwen (1996) buscaram observar o processo de produção de desenho das crianças com o objetivo de verificar como os signos são construídos e significados por indivíduos que, segundo esses autores, ainda sofrem uma menor, mas não inexistente, limitação imposta pelas convenções gráfico-sociais. Nesse aspecto, o desenho infantil em comparação ao desenho do adulto é compreendido como uma produção mais livre e mais subjetiva. Além disso, em seus estudos, os autores verificaram que a criança não desenhava o objeto inteiro, mas selecionava algumas características do objeto a ser representado. Em uma das situações investigadas nesta obra, a criança observada fez alguns círculos nomeando-os de rodas, e foram essas rodas o critério selecionado por ela para expressar sua ideia de carro. É importante verificar que essa escolha implicou em um critério elencado pelo produtor do desenho (a criança), dentre outras possibilidades, para representar o objeto inteiro. Essa seleção de critérios para a execução de uma representação, tanto em adultos quanto em crianças, é a resultante de marcas culturais, sociais e psicológicas que influenciam os sujeitos.

O estudo de Kress e Van Leeuwen (1996) sobre imagens se apoia na semiótica social de Halliday $(1976,1985)$ e pretende, assim, compreender como os 
significados são construídos e desenvolvidos pelas pessoas, considerando as especificidades culturais e sociais.

A Gramática Sistêmico-Funcional de Halliday (1976, 1985) consiste em compreender a linguagem como um sistema de significados produzidos e compartilhados pelos indivíduos na comunicação social em um determinado contexto. Esse sistema analisa como os sentidos são produzidos e utilizados por meio da linguagem em uso, bem como as escolhas dos sentidos que os indivíduos fazem, entre outras possíveis, considerando as especificidades das situações sociais. Isso quer dizer que, em si, a palavra, o gesto, a imagem, o desenho ou o diagrama não têm significado. Essa significação é realizada pelos indivíduos, quer seja pelas convenções compartilhadas pelo grupo social, quer seja pelas circunstâncias relacionadas às experiências pessoais.

A semiótica social é aplicável para a análise do discurso, tanto oral quanto escrito, em uma variedade de contextos sociais. No contexto educacional, a semiótica social vem sendo utilizada para a observação e a análise de como são construídos e estabelecidos os modos de comunicação mobilizados por professores e alunos nas aulas, bem como as linguagens presentes nos materiais didáticos que circulam nesse espaço para comunicar significados.

Ao examinar o sentido potencial da linguagem nos processos de comunicação dos indivíduos, Halliday (1985) identificou redes relativamente independentes, as quais agrupou em três funções básicas que orientam a compreensão geral da estrutura linguística, e as denominou metafunções, a saber: a ideacional, a interpessoal e a textual. Optamos, nesse momento, por apresentar as três metafunções utilizando o contexto de interesse desta pesquisa para lançar pontes entre a teoria aqui apresentada e a sala de aula de ciências dos anos iniciais do Ensino Fundamental:

- A função ideacional está diretamente relacionada com a nossa experiência e com a forma como nos relacionamos com o mundo real por meio da linguagem, ou seja, por um conjunto de signos e processos comunicativos que retratam econceituam essa mesma experiência. Ou seja, ela está diretamente relacionada com a construção das nossas opiniões e da nossa visão do mundo, estruturadas a partir da linguagem. No contexto das aulas de ciências, verificamos que esta função se relaciona com as concepções que os alunos têm sobre os fenômenos naturais, a partir de suas experiências sociais e culturais que vão sendo comunicadas e ressignificadas nos discursos orais e escritos e representadas também por meio dos desenhos produzidos pelos alunos;

- A função interpessoal consiste nas interações comunicativas estabelecidas entre os indivíduos, por exemplo, os papéis de produtor e leitor que os sujeitos assumem nas trocas de mensagem, além de delimitar e reforçar as influências exercidas pela linguagem nas esferas social e individual. Ou seja, a função interpessoal relaciona-se com os papéis assumidos pela professora e pelos alunos nas interações discursivas mediante apresentações, explicações, questionamentos e respostas no decorrer das aulas de ciências; 
- A função textual remete ao modo como as frases e as ideias estão distribuídas ao longo do texto. Essa função está relacionada ao encadeamento lógico e coerente do discurso em sua organização interna e sua inserção à situação contextual, capacitando tanto o ouvinte quanto o leitor a compreender um texto, em vez de frases desconexas e incoerentes. No contexto desta pesquisa, a função textual refere-se à coerência dos discursos da professora e dos alunos construída a partir das interações discursivas presentes em vários suportes: produções orais e escritas, desenhos dos alunos, uso de um infográfico como um suporte para explicação sobre o ciclo hidrológico, entre outros. No caso dos textos imagéticos, destacam-se elementos próprios desse modo semiótico como cores, textura, tamanho, composição estética e organização gráfica.

Halliday (1985) acrescentou, ainda, que todo enunciado exerce uma combinação dessas três funções em sua estrutura, seja na produção do discurso oral seja na do discurso escrito. Não há como dissociar a existência dessas funções que estão articuladas quando o escritor ou o falante seleciona as opções para a construção do seu discurso. Eles estão imbricados de intenções e de significações, que envolvem uma organização e um planejamento contínuo para a ocorrência eficiente de trocas de mensagens entre produtores e leitores, falantes e ouvintes.

Para Kress e Van Leeuwen (1996), o significado da linguagem visual acontece de forma independente da linguagem verbal. No trabalho de Kress et al. (1998), os autores examinam, criticamente, o papel auxiliar atribuído às imagens e aos demais modos de comunicação em sociedades dominadas pelos valores da escrita. Para contrapor a essa ideia e apresentar a contribuição de outros modos de comunicação, os autores contrastam a análise de duas atividades em livros didáticos publicados, respectivamente, no ano de 1936 e 1988. Na atividade do livro publicado em 1936, as representações visuais são ilustrativas, ancorando e repetindo as informações presentes no texto verbal escrito; na atividade do livro publicado em 1988, as imagens apresentam informações adicionais ou comunicam uma informação que não está presente no texto verbal. Nesse caso, Kress e Van Leeuwen (1996) identificam uma especialização desse modo de comunicação em relação aos outros modos. Ampliando a discussão para o contexto da sala de aula de ciências, os autores discutem como gestos, palavras, imagens, entre outros modos, podem repetir ou ilustrar as informações nos diferentes modos ou podem, ainda, assumir uma função de comunicar uma informação completa ou fazê-lo de modo especializado.

Segundo Kresse Van Leeuwen (1996), a comunicação visual, assim como os demais modos de comunicação (verbal, gestual e sonoro, entre outros), possui estrutura específica, devendo ser analisada considerando-se suas próprias possibilidades e limitações de significação. Apoiados nas ideias de Kress e Van Leeuwen (1996, p.32), levantamos algumas considerações sobre a linguagem visual que contribuem para nossa compreensão sobre seu processo de significação: 
1. A linguagem visual é sempre codificada, ou seja, não existe uma imagem em estado puro, como sugeriu Barthes ${ }^{2}$ em seus estudos publicados em 1964. Nos signos que compõem a linguagem visual existem as funções ideológica, política, social, cultural, psicológica, afetiva e cognitiva que influenciam as escolhas na composição da imagem do produtor e a leitura do leitor. Dessa maneira, tanto o processo de produção de um signo, quanto o processo de significação implicam ações muito complexas para quem o produz e também para aqueles que fazem sua leitura em busca de construção do seu significado.

2. A imagem não é uma mensagem transparente, seu sentido parece evidente, até óbvio em um primeiro momento, mas pode não ser quando verificado com mais cautela. O processo de significação só pode ser compreendido se forem considerados os códigos culturais compartilhados pelos indivíduos do grupo nos contextos sociais em que se realiza;

3. Por fim, a leitura e a compreensão de uma imagem necessitam ser ensinadas e aprendidas. A presença das representações visuais nas sociedades ocidentais tem ganhado grande ênfase no processo de comunicação. Sendo assim, cabe aos educadores e às escolas se adequar às mudanças comunicativas que as sociedades têm sofrido e proporcionar intervenções pedagógicas para que os alunos sejam capazes de utilizar os recursos dos novos arranjos semióticos, tanto como cidadãos, quanto como futuros profissionais das mais diversas áreas de atuação.

\section{METODOLOGIA}

A coleta dos dados aconteceu em uma turma do $3^{\circ}$ ano do Ensino Fundamental de uma escola pública no município de Contagem, Minas Gerais. A turma foi conduzida por duas professoras: apoio e regente, conforme organização do coletivo de professores da escola. Para o presente trabalho, observamos as aulas ministradas pela professora regente.

\section{Coleta e tratamento dos dados}

A escolha de realizar a pesquisa ${ }^{3}$ nesta escola deveu-se ao bom relacionamento da primeira autora com a professora e com a escola. A professora é pedagoga com grande experiência em alfabetização e letramento, tendo também formação em Comunicação e Marketing. Essa professora utiliza comumente imagens e desenhos nas aulas, além de conhecimentos sobre importância dos processos comunicativos nas relações de ensino e aprendizagem. Ela aceitou participar da pesquisa na condição de uma pesquisa participante, em que a pesquisadora assumiu junto com ela o planejamento e, na condição de professora auxiliar, a execução da sequência de ensino. As aulas de ciências, que ocorriam nas tardes de quinta-feira, foram acompanhadas durante todo o ano e a sequência de ensino sobre o ciclo da 
água foi desenvolvida durante dez encontros nos meses de outubro e novembro. A pesquisa foi realizada com procedimentos éticos pautados e protocolados com consentimento e anuência dos envolvidos - professora, estudantes, familiares e direção da escola.

As filmagens foram realizadas utilizando uma câmera posicionada na frente da sala e do lado esquerdo da mesa da professora. Um aparelho de áudio foi posicionado sobre a mesa da professora e outro aparelho foi posicionado no fundo da sala. Durante a execução das atividades, a pesquisadora movimentava a câmera com o objetivo de capturar as ações dos participantes. Após a realização das filmagens, os dados coletados foram capturados em formato digital e analisados recursivamente em diálogo com os problemas e propósitos da pesquisa. Os trechos mais relevantes foram, então, posteriormente transcritos. Além disso, ao longo da sequência de ensino, foram sendo recolhidas e reproduzidas as produções escritas dos alunos. A pesquisadora (primeira autora deste relato) produziu notas em caderno de campo que auxiliaram a compreensão do contexto dessa sala de aula. Quadros analíticos das aulas foram depois registrados em "mapa de eventos".

Além da análise dos desenhos e textos produzidos pelas crianças em dois momentos da sequência, utilizaremos, neste estudo, as explicações das crianças sobre seus próprios desenhos. À medida que as crianças finalizavam a atividade, se deslocavam até a mesa da professora, onde estava posicionada a filmadora e um aparelho de áudio, para uma conversa com a pesquisadora sobre o desenho produzido. A escolha de utilizar as produções dos alunos em dois momentos da sequência de ensino nos permite comparar e inferir processos de produção e apropriação de sentidos sobre o ciclo da água, objeto das interações discursivas e de atividades em sala de aula. Nesta pesquisa, tal contraste permitiu, ainda, investigar a efetividade do infográfico animado como recurso mediacional, foco de intensa interação entre estudantes e professora para produção de sentidos sobre o ciclo da água.

O primeiro momento em que os desenhos foram produzidos ocorreu ao final da primeira aula. Nessa aula, a professora realizou um levantamento das ideias preliminares dos alunos solicitando que eles levantassem palavras relacionadas ao novo tema de estudo de ciências - a água. Ao fim dessa atividade inicial e exploratória, e em função de questões levantadas pelas crianças, a professora pediu a elas que respondessem, no caderno, por meio da produção de um desenho acompanhado por uma explicação, à pergunta "De onde vem a chuva?". Na segunda aula, a professora retomou parte das palavras evocadas pelos alunos para introduzir conceitos sobre os estados físicos da água, organizou com os alunos uma legenda e utilizou tirinhas de histórias como suporte para que os alunos produzissem textos, a partir dos conceitos e ideias discutidos na aula. Na terceira aula da sequência, a professora projetou no quadro à frente da turma um infográfico animado sobre as várias etapas do ciclo hidrológico na natureza. Cada etapa do infográfico animado foi explorada e discutida com as crianças, com tempo para que se manifestassem e apresentassem suas interpretações sobre o que estava acontecendo. Após a apresentação de todo o infográfico animado, a professora decidiu reiniciá-lo, permitindo uma parti- 
cipação ainda mais intensa das crianças. No início da quarta aula da sequência, a professora distribuiu duas folhas com o título "Ciclo da água", solicitando aos alunos que produzissem um desenho e um texto sobre as informações apresentadas no infográfico animado da semana anterior.

Realizamos as análises da aula com o cuidado metodológico de contextualizar o ambiente no qual o discurso foi produzido, ou seja, com a preocupação de situar o contexto em que as atividades foram desenvolvidas e o modo como os atores envolvidos participaram da cadeia discursiva. Dessa forma, pudemos compreender como os enunciados se enlaçam e se organizam em uma construção coletiva e interativa da professora e de seus alunos, dos alunos entre si e da pesquisadora com os alunos.

\section{Sobre o infográfico animado}

O infográfico animado ${ }^{4}$ possui 13 quadros interativos que explicam as etapas do processo do ciclo da água no planeta. Informações extras estão dispostas em 12 quadros, nos botões SAIBA MAIS ou em links destacados em azul no texto. Durante todos os quadros, os textos e as imagens estão permeados de informações e detalhes a serem explorados por professores e alunos. O usuário tem a opção de avançar ou retornar informações das etapas, clicando nos botões indicados abaixo do texto. Pode ainda clicar nos oito botões que estão localizados na parte superior do infográfico animado para visualizar imagem e texto das etapas do ciclo da água. As definições dos processos do ciclo da água são apresentadas no infográfico em textos, imagens e gráficos.

Figura 1 - Primeiro quadro do infográfico animado - Ciclo da água

\section{O que é o ciclo da água?}

E a contínua circulação da água sobre o nosso planeta. Confira na animação todas as etapas desse processo, vital para a existência da vida na Terra. Clique abaixo.

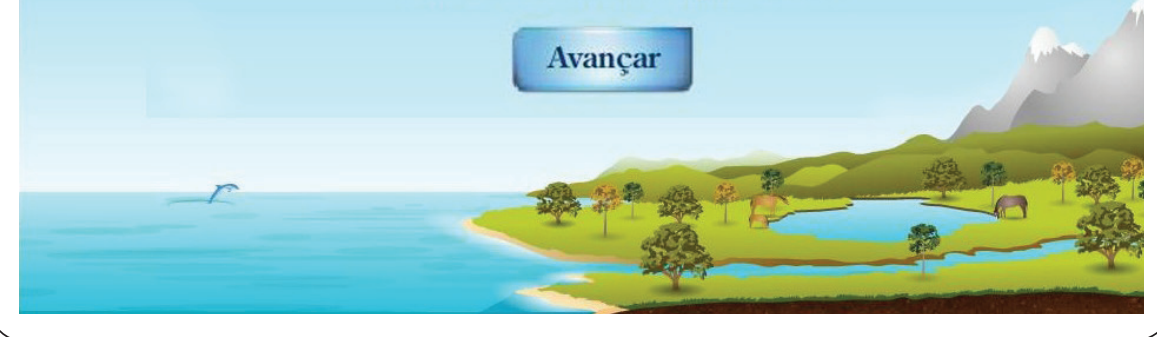

Fonte: Abril Educação 
Imagens e desenhos infantis nos processos de

construção de sentidos em uma sequência de ensino

sobre ciclo da água

Quadro 1 - Organização do infográfico animado - Ciclo da água

\begin{tabular}{|c|c|}
\hline Início & 0 que é o ciclo da água? - definição do conceito em um quadro. \\
\hline Evaporação & Definição apresentada em dois quadros e duas informações extras - texto e imagem. \\
\hline Transpiração & Definição apresentada em um quadro e duas informações extras - somente imagem. \\
\hline Sublimação & Definição apresentada em um quadro e uma informação extra- texto e imagem. \\
\hline Condensação & Definição apresentada em dois quadros sem informações extras. \\
\hline Precipitação & $\begin{array}{l}\text { Definição apresentada em dois quadros, quatro informações extras: três imagens animadas, } \\
\text { uma imagem fixa e texto. }\end{array}$ \\
\hline Escoamento & Definição apresentada em quatro quadros sem informações extras. \\
\hline Conclusão & $\begin{array}{l}\text { Síntese das informações de todo o infográfico animado em um quadro e duas informações } \\
\text { extras. }\end{array}$ \\
\hline
\end{tabular}

A professora iniciou o infográfico animado apresentando, quadro a quadro, a sua sequência. Para tal, ela utilizou como estratégia a leitura dos textos apresentados pelo infográfico animado destacando palavras importantes para a compreensão dos alunos, explicando seu significado e relacionando-as aos exemplos da vida cotidiana ou aos assuntos trabalhados nas aulas anteriores (exemplos dos estados físicos da água e os modelos de causa e efeito dos eventos). Além disso, ao longo da apresentação do infográfico animado, a professora trouxe informações adicionais e também utilizou questionamentos sobre informações ausentes naquele recurso, mas possíveis de ser inferidas pelos alunos a partir dos exemplos ali contidos, para que conseguissem estabelecer relações entre as observações da vida cotidiana e as informações do ciclo da água na perspectiva da ciência escolar.

No exemplo a seguir, apresentamos um trecho das interações discursivas entre a professora e os alunos ${ }^{5}$ para exemplificar o modo como o infográfico animado foi explorado na aula. Selecionamos o trecho da aula em que se discute o processo de condensação da água por considerá-lo representativo da dinâmica desenvolvida pela professora. O trecho foi transcrito ${ }^{6}$ na íntegra com duração de 03 minutos e 21 segundos (08:06 - 11:27).

$\mathrm{O}$ trecho transcrito corresponde a dois quadros do infográfico animado. No primeiro deles, sob um fundo azul e com pássaros, pequenas ondulações em branco, acompanhados do texto : "Condensação: depois que evapora, a água, na forma de vapor, é transportada pelas massas de ar para regiões mais altas da atmosfera." A professora lê o texto e passa ao $2^{\circ}$ quadro.

O quadro 2 contém um fundo azul, as ondulações verticais em branco terminando em formas brancas representando nuvens. A legenda é lida em voz alta pela 
professora : "Lá em cima, ao ser submetido a baixas temperaturas, o vapor se condensa e liquefaz. É assim que se formam as nuvens."

Quadro 2 - Transcrição da explicação da professora sobre a condensação utilizando o infográfico animado

\begin{tabular}{|c|c|}
\hline Sujeitos & Transcrição \\
\hline Professora & $\begin{array}{l}\text { agora vai acontecer a condensação que a gente falou tanto aqui né? ((professora chama a } \\
\text { atenção de uma aluna que estava em pé)) ((um aluno lembra do leite condensado pela se- } \\
\text { melhança do nome)) é quando a gente falou de leite condensado. A condensação / ((lendo } \\
\text { o texto do infográfico)) “Depois que evapora, a água, em forma de vapor, é transportada } \\
\text { pelas massas de ar para regiões mais altas da atmosfera” // Então é aquilo que eu falei, todo } \\
\text { esse ar que sai ali que a gente/ vão lembrar da chaleira primeiro, todo esse ar que sai da } \\
\text { chaleira e que sai ali dos rios, que sai dos animais, que sai das pessoas... ((gesticula fazendo } \\
\text { movimentos ascendentes com as mãos)) }\end{array}$ \\
\hline Cristina & das plantas. \\
\hline Professora & $\begin{array}{l}\text { que sai das plantas, ela sai em forma de:: vapor. E elas vão subindo ((gesticula com as duas } \\
\text { mãos em um movimento ascendente)) para a:: }\end{array}$ \\
\hline Muitos alunos & atmosfera. ((professora repete a palavra)) \\
\hline Professora & $\begin{array}{l}\text { aí elas continuam subindo, subindo bem alto, porque a nuvem não fica bem lá no alto?((estica } \\
\text { os braços acima da cabeça e para as mãos balançando-as)) } \\
\text { Aí o que acontece/como é que ela condensa? Quando ela tá bem lá no alto, ela encontra } \\
\text { massa de ar frio, aí ((chama a atenção de dois alunos)) lá em cima, lá na atmosfera, lá bem no } \\
\text { alto ((estica os braços novamente acima da cabeça)), é frio, a temperatura não é quente igual } \\
\text { é na terra. Então quando ela tá bem lá em cima, bem lá no alto, ela encontra massas que a } \\
\text { gente chama de ar frio,((um aluno diz massa de ar polar, mas a professora reforça o termo } \\
\text { que usava anteriormente)) massas de ar fria. Então quando esse vaporzinho vai subindo e } \\
\text { encontra essa massa de ar frio, ele passa forma as nuvens... }\end{array}$ \\
\hline Iago & $\begin{array}{l}\text { professora, mas quando o: esse/quando vai subindo da sobre a terra/mas sai do planeta } \\
\text { ou fica? }\end{array}$ \\
\hline Professora & não fica aqui dentro ele se condensa lá em cima. O que que é condensar? \\
\hline Alguns alunos & $(($ inaudível)) \\
\hline Professora & $\begin{array}{l}\text { é quando a água passa daquele estado do vapor pro estado líquido.((a professora gesticula } \\
\text { abrindo e fechando as mãos)) Aí ela vai juntando e vai formando umas gotinhas pequenini- } \\
\text { nhas, pequenininhas, aí/ a subiu o vapor transforma as gotinhas ((repete o movimento de } \\
\text { fechar com a mão esquerda e gira o dedo da mão direita no momento em que fala a palavra } \\
\text { transforma)) é:: o vapor é transformado em gotinhas pequenininhas, uma gotinha junta } \\
\text { com a outra que junta com a outra... }\end{array}$ \\
\hline Cristina & Gotículas. \\
\hline Professora & $\begin{array}{l}\text { que são aquelas gotículas. Sabia que uma gotinha dessa é cem, pensa no ponto final que a } \\
\text { gente coloca na frase... não é pequenininho? }\end{array}$ \\
\hline
\end{tabular}


Imagens e desenhos infantis nos processos de

construção de sentidos em uma sequência de ensino

sobre ciclo da água

\begin{tabular}{|c|c|}
\hline Cristina & Ahã. \\
\hline Professora & essa gotinha é cem vezes menor do que o ponto final. \\
\hline Alguns alunos & NU::: \\
\hline Professora & [então precisa de quê? Muitas gotinhas prá formar lá em cima o quê? \\
\hline Iago & [precisa de uma ampulheta prá ver ((referindo-se provavelmente a uma lupa)) \\
\hline Professora & as o quê? As nu... \\
\hline Alguns alunos & as nuvens. A chuva. \\
\hline Professora & $\begin{array}{l}\text { [as nuvens. Elas vão se juntando, as gotinhas vão se juntando. ((a professora avança mais um } \\
\text { quadro do infográfico animado para continuar sua explicação)) Aqui, aqui já explica olha } \\
/ / \text { ((a professora lê o texto do quadro } 2 \text { do infográfico }) \text { "Lá em cima, ao ser submetido } \\
\text { às baixas temperaturas, psiu::: o vapor se condensa e se liquefaz. É assim que surgem as } \\
\text { nuvens." /É aquilo que eu havia explicado antes / me antecipei aqui. }\end{array}$ \\
\hline Iago & [o vapor sobe aí/ aí fica uma água dentro da nuvem, aí quando chove... \\
\hline Professora & $\begin{array}{l}\text { [se condensa...fica dentro da nuvem não, a água é que forma essa nuvem. As gotinhas } \\
\text { que vão se juntando que formam a nuvem. ((chama a atenção de duas alunas que estavam } \\
\text { conversando)) }\end{array}$ \\
\hline
\end{tabular}

Não é foco deste trabalho examinar, em detalhe, os modos como a professora explora as informações do infográfico com os estudantes, mas não podemos nos furtar a fazer algumas considerações a esse respeito. Isso porque o potencial de significação desse recurso depende dos modos como suas informações são apresentadas e entrelaçadas com as vozes e os interesses das crianças. No caso aqui investigado, destacamos a atenção da professora em conduzir a apresentação do infográfico em duas etapas nessa aula. a busca dar sentido às palavras novas que aparecem no texto projetado e estabelecer vínculos com as experiências das crianças, com as imagens e com as discussões realizadas nas aulas anteriores. É assim que o signo "condensação" vai sendo apresentado em conexão com a narrativa que foi sendo construída com os recursos do infográfico: a água que havia evaporado (para tal a professora menciona experiências com a chaleira, e a evaporação da água dos rios e dos corpos dos animais e plantas) vai encontrando o ar frio "lá no alto" e então "juntando e formando gotinhas", processo que vai ser, a partir de então, nomeado pela palavra "condensação". A narrativa parece encantar as crianças com o inusitado - gotinhas cem vezes menores que um ponto final em uma frase.

Ao finalizar a primeira apresentação, a professora voltou, então, ao 
início do infográfico, retomando ponto a ponto as etapas do ciclo, dessa vez dando mais oportunidades para que as crianças falassem sobre o que estavam observando. Nesse momento da aula foi possível perceber que sua intenção era a de retornar a algumas etapas para esclarecer dúvidas da turma, mas também de reforçar a integração de todas as etapas para que os alunos as compreendessem como partes que compunham um ciclo único e contínuo da água na natureza. Por essa dinâmica a professora e os alunos narraram novamente toda a história das etapas do processo, possibilitando a construção de um desfecho que sinalizava a continuidade do ciclo da água na natureza. Assim, essa narrativa científica, diferentemente de outras narrativas, revelava, em seu fim, um recomeço.

\section{Analisando as produções dos alunos}

A professora iniciou a quarta aula solicitando aos alunos que fizessem um desenho e um texto verbal sobre informações que os alunos conseguissem lembrar sobre as imagens do infográfico animado discutido na semana anterior. É importante ressaltar que, para o desenvolvimento dessa atividade, a professora não projetou a imagem no quadro, tudo o que foi produzido pelos alunos foi resultado da lembrança individual e,em alguns momentos, lembranças coletivas através de comentários e trocas de informações que ocorreram esporadicamente.

Além da análise dos desenhos e textos escritos produzidos pelas crianças nos dois momentos da sequência de ensino, utilizamos, neste estudo, as explicações das crianças sobre seus próprios desenhos, buscando verificar, assim, o significado atribuído pela criança à sua produção. Para isso recorremos a Vygotsky (2001, p. 479) a fim de compreender que "o pensamento não se exprime em palavra, mas nela se realiza".

Valemo-nos, ainda, dos apontamentos de Ferreira (1998, p. 35) sobre a configuração cultural e social dos significados dos desenhos:

Os conceitos e os significados são produzidos, reproduzidos e modificados pela linguagem. Os significados das figurações do desenho da criança são culturais e produto das suas experiências com os objetos reais mediadas pela palavra e pela interação com o "outro". A percepção da criança é configurada pelos significados culturalmente produzidos e seu desenho é indicativo disso.

\section{RESULTADOS}

Do total de 25 alunos da turma, na primeira atividade, foram coletadas 19 produções de textos verbais e desenhos dos estudantes; na segunda atividade, foram entregues 20 produções. Na primeira produção dos alunos, de um modo geral, os textos verbais escritos e os desenhos apresentaram características similares: textos verbais escritos curtos (solicitados pela professora) contendo explicações relacionadas ao vapor que sobe para a nuvem e faz 
cair a chuva, desenhos que reproduziam as representações de nuvens e riscos que simbolizavam a chuva, pessoas com guarda-chuvas, raios e trovões e o repertório oral limitado. $\mathrm{Na}$ segunda produção os alunos construíram textos verbais escritos mais extensos com ecos de palavras que apareceram no discurso da professora durante suas explicações e no texto verbal escrito do infográfico animado. É possível notar ainda que, nessas produções, alguns alunos reproduziram partes das etapas do ciclo da água apenas no desenho ou apenas no texto verbal escrito, outros procuraram sintetizar todas as informações no texto verbal escrito e no desenho e houve aqueles que explicaram coisas diferentes no texto verbal escrito e no desenho. Os gráficos 1 e 2 sintetizam a diversidade de textos verbais escritos e desenhos produzidos pelos estudantes na segunda etapa da atividade. As categorias utilizadas nessa síntese foram sendo construídas paulatinamente na análise dos dados e validadas a partir da colaboração de duas pesquisadoras ${ }^{7}$. Os gráficos 1 e 2 sistematizam os resultados. Como se pode ver, as categorias não são excludentes e, por essa razão, o total excede o número de produções (20):

Gráfico 1 - Características dos textos verbais escritos produzidos pelos alunos após a animação

\section{Características dos textos verbais escritos produzidos pelos estudantes}

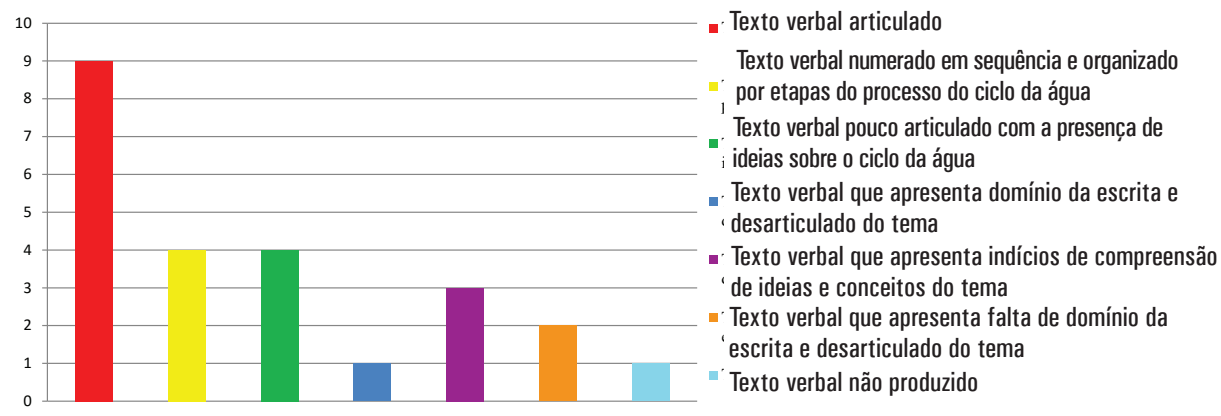

\begin{tabular}{|l|l|}
\hline Características observadas nos textos & Frequencia \\
\hline Texto verbal articulado & 9 \\
\hline Texto verbal numerado em sequência e organizado por etapas do processo do ciclo da água & 4 \\
\hline Texto verbal numerado em sequência e organizado por etapas do processo do ciclo da água & 4 \\
\hline Texto verbal que apresenta domínio da escrita e desarticulado do tema & 1 \\
\hline Texto verbal que apresenta indícios de compreensão de ideias e conceitos do tema & 3 \\
\hline Texto verbal que apresenta falta de domínio da escrita e desarticulado do tema & 2 \\
\hline Texto verbal não produzido & 1 \\
\hline
\end{tabular}


Gráfico 2 - Características dos desenhos produzidos pelos alunos após a animação

Características dos desenhos produzidos pelos estudantes

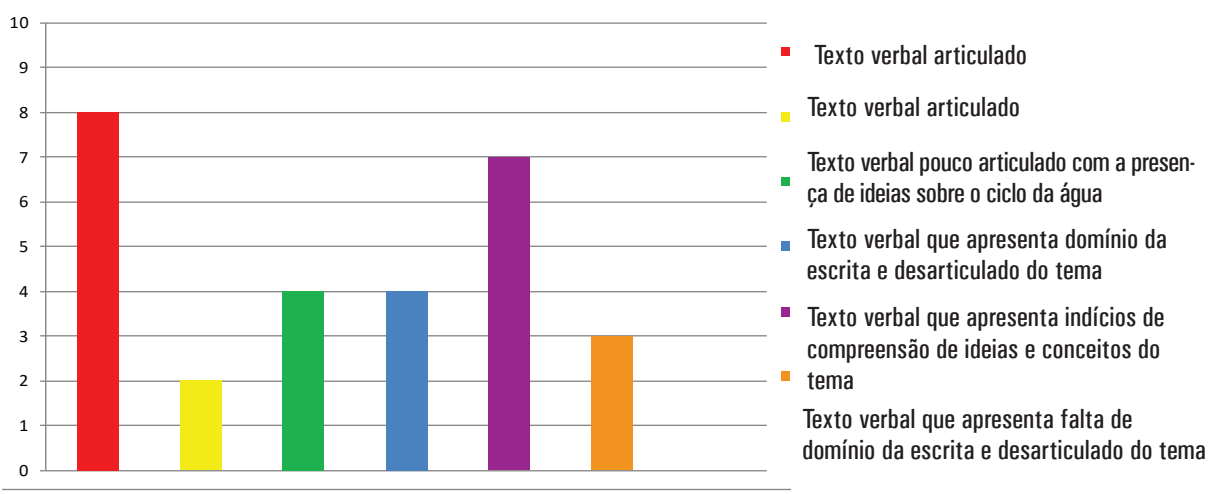

\begin{tabular}{|l|l|}
\hline Características observadas nos textos & Frequencia \\
\hline Desenho que utiliza a representação de setas circulares & 8 \\
\hline Desenho síntese das imagens apresentadas sobre o ciclo da água & 2 \\
\hline Desenho numerado em sequência e organizado por etapas do processo sobre o ciclo da água & 4 \\
\hline Desenho organizado em quadrinhos sem numeração & 4 \\
\hline Desenho que apresenta pelo menos um conceito ou ideias discutidos nas aulas sobre o tema & 7 \\
\hline Desenho que não apresenta conceitos ou ideias evidentes sobre o ciclo da água & 3 \\
\hline
\end{tabular}

Fonte: Autores

Para a realização das análises, selecionamos as produções de quatro estudantes, a saber: as produções de textos verbais orais (explicações sobre os próprios desenhos), textos verbais escritos (produções textuais escritas) e os desenhos produzidos na primeira e na quarta aula da sequência de ensino. Consideramos como critérios para a escolha das produções a participação do aluno nas duas aulas em que ocorreram as produções relacionadas ao infográfico animado e a originalidade do desenho e/ou dos textos. Os textos verbais orais dos alunos serão comentados e inseridos no texto de análise com o objetivo de esclarecer alguma situação contextual ou reforçar alguma concepção do aluno, verificada no momento das explicações dos desenhos. Por esse motivo, não iremos transcrevê-los na íntegra.

$\mathrm{Na}$ sequência apresentaremos as produções de Iago, Suzana, Cauã e Lucas. Em todas elas estão dispostas as imagens das produções dos textos verbais escritos, dos desenhos dos alunos, as transcrições dos textos verbais respeitando a escrita original da criança e, quando necessário para análise, a transcrição do texto verbal oral ou a utilização das imagens do infográfico animado que inspiraram os desenhos produzidos. 


\section{As produções de lago}

Iago era um estudante sorridente e muito participativo nas aulas. Ele, quase sempre, fazia questão de contribuir com algum tipo de informação nas discussões propostas pela professora. Sua vontade de participar era tanta que, em alguns casos, a professora solicitava que ele esperasse um pouco para falar. primeira aula.

Reproduzimos, nas figuras 5 e 6 , textos e desenhos, produzidos por lago na

Figura 5 - Produção do lago na primeira aula.

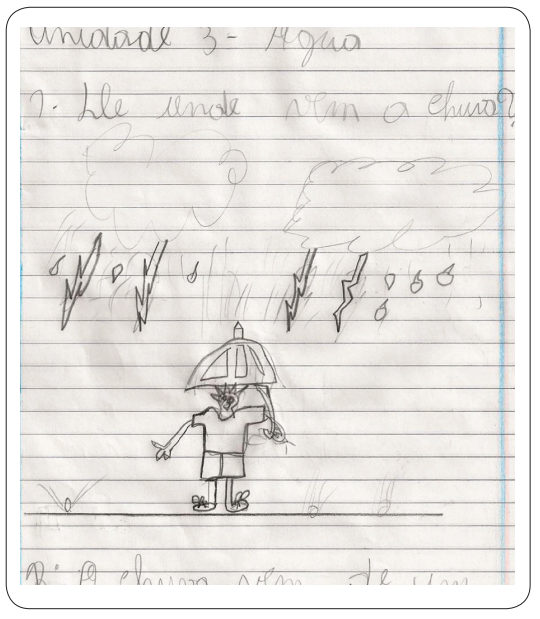

Figura 6 - Continuação do texto de lago na primeira aula.

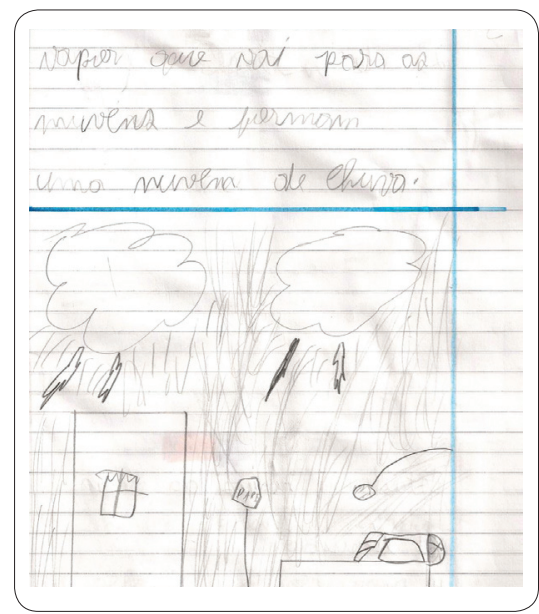

Transcrição do texto verbal de Iago na primeira aula: "De onde vem a chuva? A chuva vem de um vapor que vai para as nuvens e formam uma nuvem de chuva".

Na semana seguinte à aula com o infográfico animado Iago reproduziu o seguinte desenho e texto:

Figura 8 - Desenho de lago após a animação

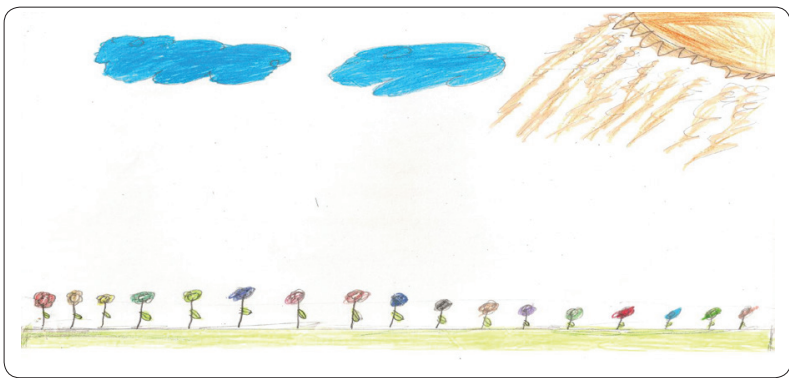

Transcrição do texto de Iago após animação:

No dia 30/09/10 a professora mostrou a gente o ciclo da água.

Eu via o sol aquecendo a água, o sol soltou os seus raios solares para aquecer a agua e o solo.

Depois de aquecer a agua e o solo o

vapor comecou a sair do solo.

Depois caiu a chuva de granizo e a neve

Quando a chuva de granizo e a neve acabou a neve ficou na geleira.

Depois a agua da chuva virou poças

A agua da chuva que virou poças escorre para de baixo do solo. 
$\mathrm{Na}$ primeira produção Iago optou por desenhar duas nuvens com raios e gotas de água, que parecem representar uma forte chuva e um menino no centro do desenho segurando um guarda-chuva para não se molhar. Ao ser questionado sobre os raios, representados no desenho, sem ter sido feita qualquer referência no texto escrito, o aluno informou desconhecer sua origem, não arriscando nenhuma explicação para o fenômeno. Quando a pesquisadora solicitou mais informações sobre o seu desenho, Iago disse que não havia terminado sua atividade. No fim da conversa o aluno voltou a dizer à pesquisadora que completaria seu desenho. O aluno retornou com um desenho de duas nuvens, raios, um prédio (o aluno reside em um apartamento), dois postes e um automóvel, mas não achou necessário explicá-lo.

Em sua segunda produção, Iago escreveu um texto verbal contendo várias informações parecidas com tópicos, desconexas e sem uma progressão de ideias. Nessa ocasião, seu desenho apresentou elementos básicos sem conceitos evidentes sobre o ciclo da água: um sol radiante (o único elemento comum ao texto), duas nuvens, flores e um gramado por toda a extensão da folha de papel. Em seu texto oral, Iago pareceu não ter certeza sobre a evapotranspiração das plantas e a evaporação da água que está no solo. Quando questionado sobre o restante do ciclo manifestou dúvidas. Ao ser perguntado se queria acrescentar mais alguma informação ao seu desenho, o aluno respondeu que estava bom, não sendo necessário dizer mais nada. Com o intuito de verificar quais conhecimentos o aluno conseguiu construir, a pesquisadora pediu ao aluno que explicasse o que havia acontecido com as nuvens presentes em seu desenho. $\mathrm{O}$ aluno descreveu que o raio desceu e o vapor subiu para formar uma nuvem de chuva. Quando questionado sobre como a água subia para as nuvens, o aluno disse que não sabia. Incentivado pela pesquisadora, Iago disse acreditar que o vapor do solo subia e formava a nuvem de chuva. De acordo com suas explicações, a nuvem parece ser um recipiente que enche e, quando fica em seu limite, solta a água. Após essa explicação, no fim da conversa, o aluno pareceu compreender, mesmo que de forma incipiente, a ideia de ciclo: "é, aí depois forma e vai mesmo aquilo que eu falei. Aí a água cai forma as poças de, poças de... poças de água, escorre vai pro solo e depois forma o vapor e vai prá nuvem de novo e depois cai”. 


\section{As produções de Cauã}

Cauã era tímido para expor suas ideias para a turma, mas cumpria todas as atividades propostas pela professora com muito capricho.

Reproduzimos, na figura 15, texto e desenho de Cauã na primeira água.

\section{Figura 15 - Produção de Cauã na primeira aula}

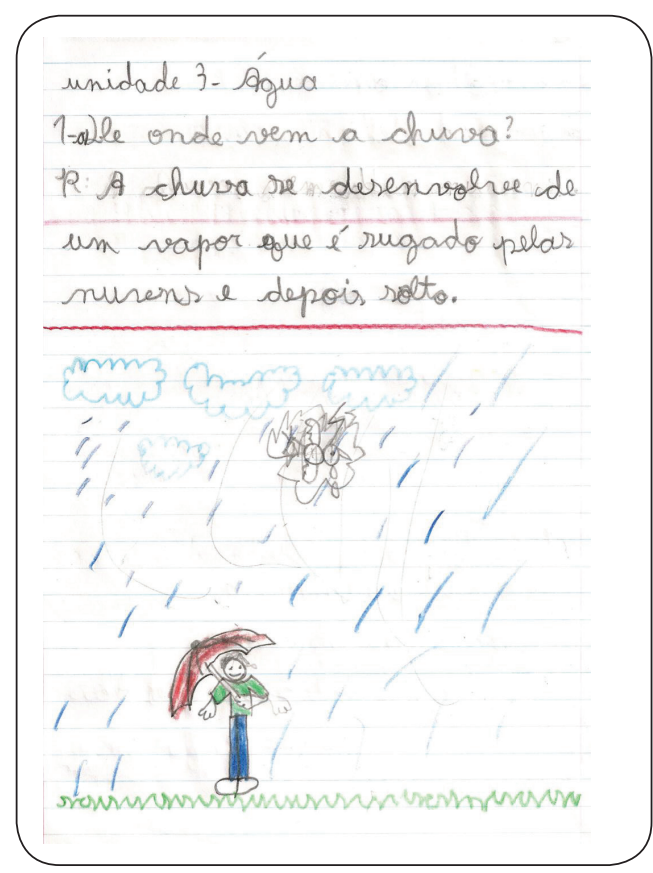

Transcrição do texto escrito de Cauã após o infográfico animado:

1-Os raios do sol estam aquecendo a água do rio.

2- Depois de aquecida pelo sol a água vai virando vapor aos poucos.

3- O vapor da água esquentada pelo sol vai subindo bem devagar para a atimosfera até chegar a um ponto bem alto.

4- E quando já estiver chegado a um ponto bem alto da atimosfera, vai formando as nuvems.

5- Nas nuvems têm pequenas goticulas e essas gotículas vam se juntando e formando gotas maiores e mais pesadas.

6- Essas gotas formadas pelas goticulas caem formando a chuva.

7- A chuva cai ne rios, transbordando e formando possas.

8- O solo vai sugando (Enfiltrando) apossa.

Figura 17 - Desenho de Cauã após a animação.

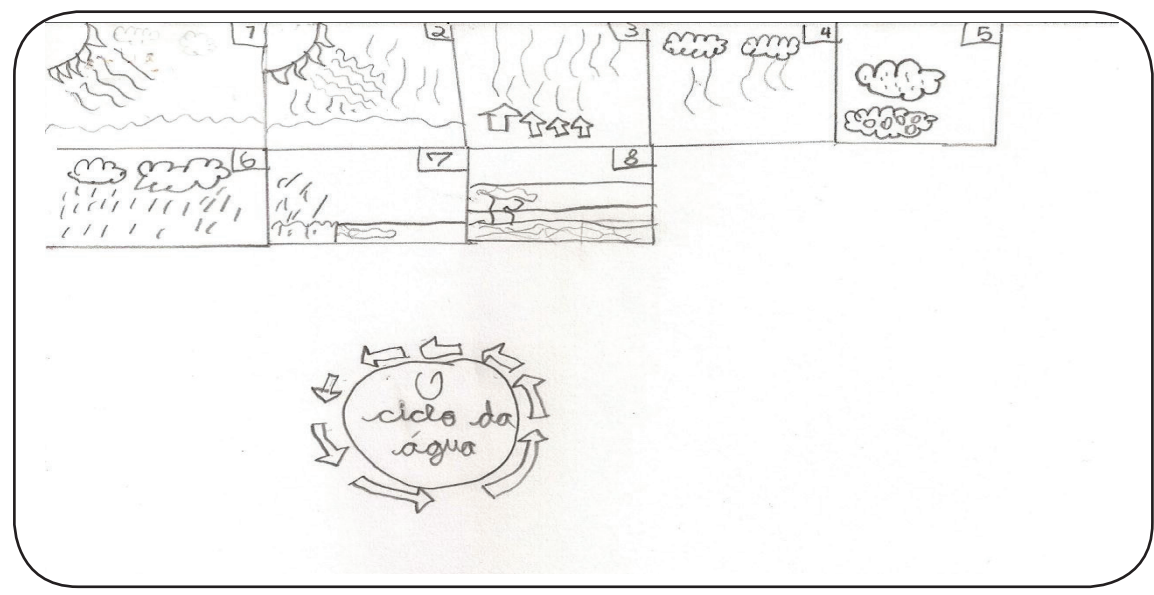


O primeiro desenho de Cauã, semelhante ao primeiro desenho de Iago e Suzana, apresentou algumas nuvens, riscos representando a chuva, um menino com um guarda-chuva e um passarinho voando no céu. Para Cauã, nessa representação, a nuvem também parece ser um recipiente que armazena a água até encher para depois se esvaziar. Essa evidência é reforçada por suas palavras no texto verbal: a chuva se desenvolve de um vapor que é sugado pelas nuvens que depois solta.

$\mathrm{Na}$ segunda produção de Cauã, texto verbal escrito e desenhos foram organizados em uma sequência numerada. Essa forma de organização do texto verbal escrito possibilitou uma coerência na apresentação das ideias sobre o ciclo. É possível verificar em sua escrita uma retomada dos conceitos da etapa anterior do ciclo seguida da apresentação de novas informações sobre o processo, além de uma evidente ampliação de repertório. As palavras atmosfera, gotículas, poças, infiltra, ciclo, circulação da água, mencionadas no texto do infográfico e nas explicações da professora, foram expressas com propriedade nos textos verbais: oral e escrito do aluno. A seguir apresentamos um trecho da explicação de Cauã sobre sua produção para exemplificar como o aluno se apropriou das palavras alheias, incorporando-as ao seu discurso

Quadro 4 - Transcrição da explicação de Cauã sobre 0 desenho que produziu

\begin{tabular}{|l|l|}
\hline Sujeitos & \multicolumn{1}{c|}{ Transcrição } \\
\hline Cauã & $\begin{array}{l}\text { aí aqui o sol tá esquentando a água, aqui é a primeira parte. Aí o sol esquentando } \\
\text { aí a água vai virando vapor ela expande. aí aqui no terceiro o vapor vai subindo } \\
\text { pro ponto mais alto, pro ponto muito alto da atmosfera, aí numa quarta etapa, aí } \\
\text { ela, aí vai }\end{array}$ \\
\hline Pesquisadora & aqui o vapor subiu... \\
\hline Cauã & $\begin{array}{l}\text { prá um ponto muito alto da atmosfera e quando che... e quando o vapor chegou } \\
\text { num ponto bem alto da atmosfera aí foi formando as nuvens, aí nas nuvens ficou } \\
\text { pequenas gotículas e essas gotículas vão se juntando e formando gotas mais pesa- } \\
\text { das e mais...e maiores, aí dessas gotas mais pesadas, aí vão ficando mais carregadas } \\
\text { as nuvens e vão, aí chove, aí a chuva que saiu das nuvens, aí caiu, aí caiu num rio ou } \\
\text { lagoa, aí foi transbordando formando as poças, aí é no final, que é a última parte, } \\
\text { dessas poças o solo foi infiltrando é a água. }\end{array}$ \\
\hline
\end{tabular}

\section{As produções de Lucas}

Lucas demonstrava gostar muito de expor suas ideias nas aulas de ciências. Era atento a tudo o que a professora explicava e, com certa frequência, realizava perguntas para a professora sobre os assuntos abordados.

$\mathrm{Na}$ figura, reproduzimos texto verbal escrito e desenho de Lucas na primeira aula. 
Figura 18 - Produção de Lucasna primeira aula.

Figura 19 - Continuação do desenho de Lucas na primeira aula.
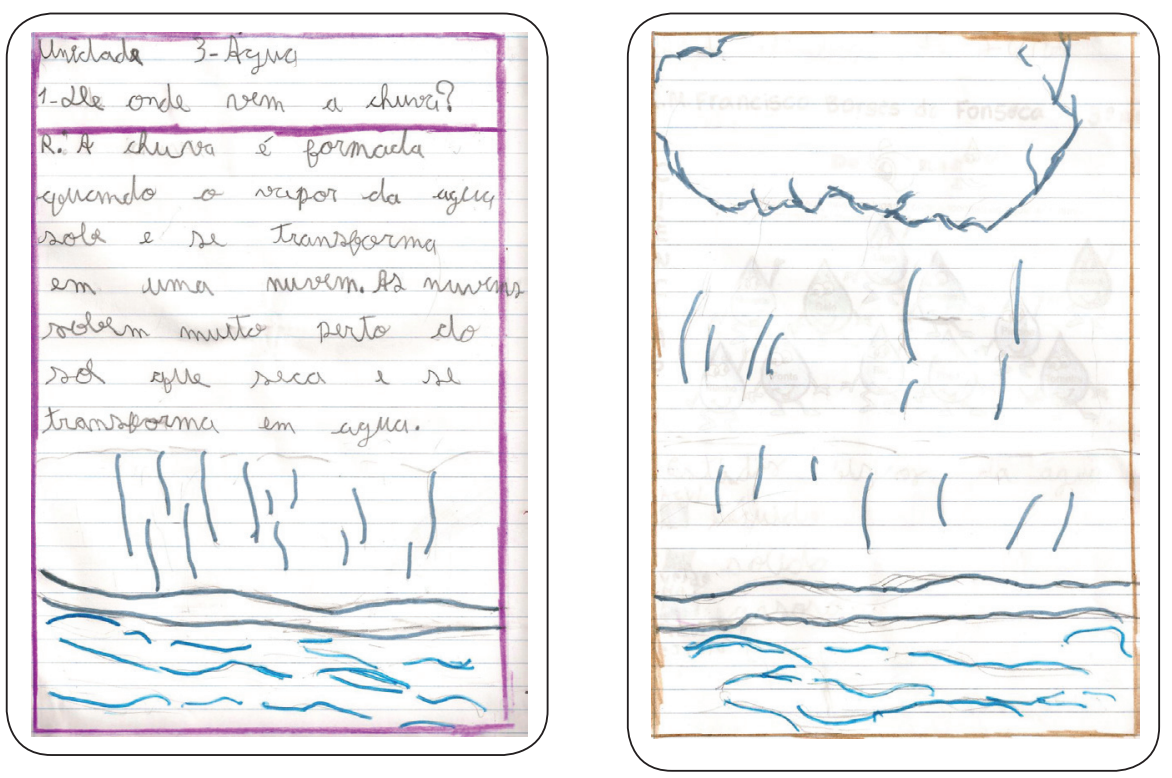

Transcrição do texto verbal escrito de Lucas na primeira aula: De onde vem a chuva?"A chuva é formada quando o vapor da agua sobe e se transforma em uma nuvem. As nuvens sobem muito perto do sol que seca e se transforma em agua". Na semana seguinte à aula com o infográfico animado, Lucas.

Figura 22 - Desenho de Lucas após a animação.

Figura 22 - Desenho de Lucas após a animação.
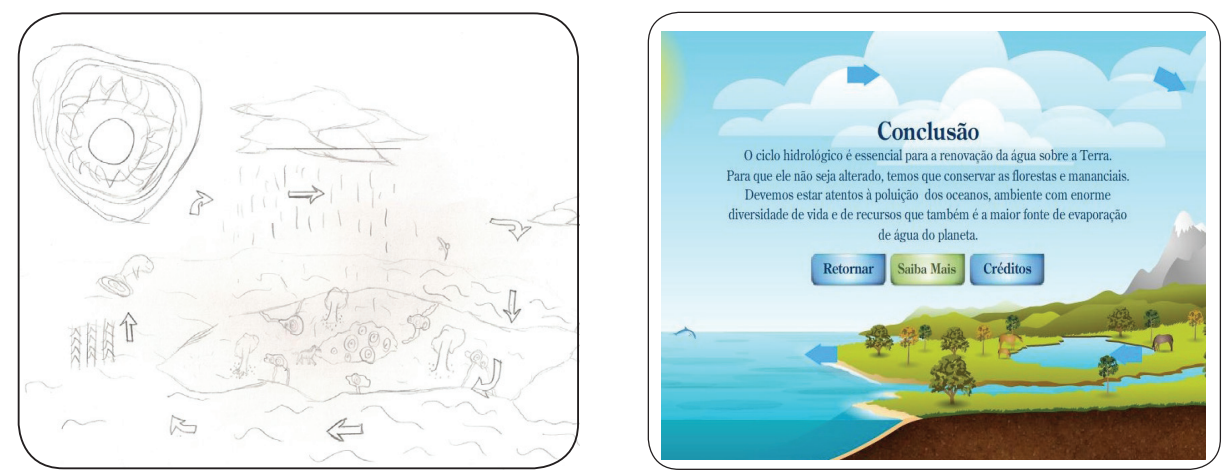

Transcrição do texto verbal escrito de Lucas após oinfográfico animado:

A água evapora vai para o céu encontra uma camada fria de ar se transforma e pingos e esses pingos vão se juntando até virar uma grossa camada de água e vão virando uma grande camada de ar que nós chamamos de "nuvens".

os pingos vão crecendo até que ficam muito pesados e caem. A água vai formando em poças que vão escorrendo indo para plantas, terra... quando ele vai para terra ele vai se misturando e fazendo uma cobertura d’água embaixo da terra.

Indo para plantas, ervas, árvores etc. Formando um circolo em volta da terra e como chamamos de o "ciclo da água. 
Em seu primeiro desenho, Lucas utilizou um espaço, logo abaixo de seu texto, para desenhar uma porção de riscos no formato de ondas na horizontal, representando a água na parte inferior da folha de seu caderno, e riscos na vertical representando o vapor. Devido à limitação espacial para desenhar a nuvem, ocupada pelo texto, o aluno resolveu reproduzir o desenho na folha seguinte de seu caderno. Em sua explicação sobre a chuva, o aluno descreveu sua ideia sobre a evaporação, sem utilizar essa palavra, tanto em seu texto quanto em seu desenho. Para o aluno, nesse momento, o vapor de água se transformou na nuvem e o sol, único elemento que apareceu no texto e não foi representado no desenho, foi o responsável por secar a nuvem para ocorrer a chuva.

Em sua segunda produção, de forma muito original, Lucas conseguiu sintetizar tanto em seu desenho quanto em seu texto as várias etapas do ciclo da água. Nessas produções evidenciou-se a ampliação de repertório em seus textos escrito e oral, bem como em suas representações por meio do desenho. $\mathrm{O}$ aluno conseguiu estabelecer relações entre os processos, demonstrando ter compreendido as ideias sobre o ciclo da água. No entanto, devido à quantidade de informações sobre o assunto apresentadas à turma e por se tratar de um assunto recentemente discutido, o aluno apresentou dificuldades em nomear algumas etapas dos processos tratados na sala de aula. Essas dificuldades não influenciaram na qualidade apresentada em seu trabalho e nos avanços verificados em suas produções.

\section{CONSIDERACְÕES FINAIS}

Verificamos em nossos dados (exemplificados aqui na produção de três estudantes) que as crianças dessa turma foram capazes de produzir textos verbais orais e escritos e desenhos, repletos de informações e conceitos complexos, elaborados de modo muito sofisticado sobre as etapas do ciclo da água. Considerando as contribuições de Vygotsky (2001) sobre as formulações do desenvolvimento do pensamento e da linguagem mediados por signos socioculturais, os desenhos dos estudantes dessa turma eram muito mais que representações aleatórias produzidas para atender a uma solicitação feita pela professora. Eles se apresentam, ao contrário, como resultado de um trabalho intelectual criativo de intensa elaboração conceitual. Embora alguns alunos não conseguissem ainda explicar um determinado conceito por meio dos textos verbais (oral e escrito), em seus desenhos encontramos indícios de sua compreensão sobre processos envolvendo o ciclo da água na natureza.

Ao analisarmos as produções dos alunos nos dois momentos da sequência, observamos que a utilização do desenho e dos textos verbais pode apresentar informações semelhantes ou diferentes dependendo da relação que o aluno estabelece com estes materiais, considerando alguns aspectos tais como: domínio ou facilidade de produção e reprodução do assunto nas diferentes linguagens, os conhecimentos do aluno sobre o tema proposto e a influência dos outros sujeitos no processo de produção da atividade.

Outro aspecto importante verificado em nossas análises faz referência às relações es- 
tabelecidas entre as linguagens (os textos verbal oral e verbal escrito e o desenho) na comunicação das ideias dos alunos sobre o tema ensinado. De acordo com os dados observados, essas relações aconteceram quando:

- os textos e os desenhos apresentavam ideias semelhantes e articuladas - texto verbal e desenho fazem referência aos mesmos elementos e relações de causalidade dos eventos e processos sobre o ciclo da água. O desenho utiliza a representação do ciclo através de setas dispostas em círculos (textos verbais escritos e desenhos de Suzana e Cauã após a apresentação da animação);

- $\quad$ ideias diferentes e complementares - elementos presentes nos textos verbais completam informações dos desenhos e vice-versa (texto verbal escrito de Lucas após a apresentação da animação);

- $\quad$ ideias diferentes e não complementares - o texto verbal escrito e o desenho apresentam informações ou ideias que não se completam sobre a causalidade dos eventos e processos envolvidos (texto verbal escrito e desenho de Iago após a apresentação da animação).

Em relação às contribuições do infográfico animado como um recurso mediacional, observamos, nas produções dos alunos, evidências da ampliação do seu repertório e de suas ideias sobre as etapas do ciclo da água. Os estudantes da turma pesquisada já produziam textos verbais escritos com muita qualidade. No entanto, pudemos observar que esses estudantes não apenas reproduzem o vocabulário utilizado pela professora e presentes no infográfico animado, mas o fazem com propriedade e os utilizam para significar o "ciclo da água". Trazem, ainda, suas próprias explicações e informações adicionais sobre os conceitos trabalhados na aula. Conforme nos apontam os trabalhos de Kress e Van Leeuwen (2001), Kress et al. (2001) e Kress e Bezemer (2009), textos verbais oral e escrito, imagens, gestos, sons, entre outros, são concebidos como diferentes modos ou multimodos que constituem a comunicação humana. Nesse caso, o infográfico animado foi um recurso multimodal utilizado pela professora para orientar o discurso sobre o tema trabalhado.

Conforme pudemos observar, o infográfico também possibilitou, enquanto recurso multimodal, que a professora discutisse com a turma as limitações encontradas nos diferentes modos de representação. Apoiados nos trabalhos de Lemke (1990) e Kresset al. (2001), o emprego de vários modos comunicativos, utilizados como uma estratégia que busca superar as limitações existentes aos instrumentos que medeiam as ações humanas, pode ajudar a minimizar a presença de possíveis lacunas nos processos de ensino e aprendizagem.

Destacamos a importância das interações entre a professora e os estudantes mediados pelo infográfico animado como determinantes desse bem-sucedido processo de apropriação de ferramentas culturais. Chamamos atenção, ainda, para o uso de diferentes estratégias para tal, ao longo das aulas que compõem a sequência de ensino. Nesse sentido, a aula com o infográfico animado não pode ser analisada sem conexão com as anteriores e com as aulas seguintes. Dessa forma, segundo Kress et al. (2001), 
compreendemos que a comunicação construída no contexto da sala de aula é, por essência, multimodal, em que os vários recursos semióticos são orquestrados (verbal, gestual, visual, sonoro, entre outros) pela professora para comunicar à turma os conceitos e as ideias das ciências sobre o ciclo da água na natureza.

Assim como os estudos de Martins, Gouvêa e Piccinini (2005) e Martins e Gouvêa (2005), verificamos que existem diferentes formas de engajamento dos estudantes com as imagens (afetiva, estética e cognitiva), bem como os conhecimentos prévios que os estudantes trazem para a sala de aula. Em nossas análises pudemos revelar que essas diferentes formas de engajamento dos estudantes também ocorrem com os desenhos e os textos verbais oral e escrito que eles mesmos produziram.

Neste trabalho examinamos os desenhos como uma atividade didática que nos possibilitam elencar um grande número de informações sobre as concepções dos estudantes e ter acesso aos significados atribuídos à sua produção e, consequentemente, à compreensão de suas ideias sobre o tema que foi discutido nas aulas analisadas. Essas observações evidenciam a importância de um trabalho em sala de aula que considere relevantes as diferentes linguagens produzidas pelos alunos como valiosos instrumentos de construção do seu conhecimento.

\section{NOTAS}

${ }^{1}$ Utilizamos neste trabalho os termos animação ou infográfico animado para as imagens sobre o ciclo da água apresentadas e discutidas na terceira aula da sequência de ensino sobre o tema.

\section{${ }^{2}$ Cf. BARTHES, 1982.}

${ }^{3}$ A pesquisa foi aprovada pelo COEP - UFMG - Comitê de Ética em Pesquisa da Universidade Federal de Minas Gerais, número 0045.0.203.000-11

${ }^{4} \mathrm{O}$ infográfico animado utilizado pela professora como um recurso imagético para explicar as várias etapas do ciclo hidrológico foi desenvolvido pela empresa Cricket Designe estava disponibilizado pela Editora Abril Educação no site: http://www.cricketdesign.com.br/ abril/ciclodaagua/ com um plano de orientações didáticas sobre o tema para o Ensino Fundamental.

${ }^{5}$ Foram utilizados nomes fictícios para os sujeitos da pesquisa.

${ }^{6}$ Procuramos manter nas transcrições fidelidade ao que foi enunciado, transcrevendo os termos exatamente como ouvimos. Buscamos situar, com o mesmo cuidado, o contexto da atividade. As falas dos sujeitos foram transcritas em itálico. Adotamos o código de Mussalime Bentes (2001) para registrar uma pontuação à língua oral. Para indicar uma mudança no tom, indicativa de uma pergunta ou uma exclamação, foram mantidos o ponto de inter- 
rogação (?) e o ponto de exclamação (!). Os comentários, por parênteses duplos ((comentário)). O alongamento de vogal de uma palavra foi indicado por dois pontos,(:) pequeno, (::) médio, (:::) grande. A barra,(/), indica um truncamento de palavras ou desvio sintático. O colchete simples, [, sinaliza superposição de vozes. O duplo colchete, [[, sinaliza o início e o fim de duas falas simultâneas. As pausas na fala por três pontos (...). A ênfase na palavra pela escrita maiúscula (LIMPINHA).

${ }^{7}$ As categorias foram validadas por duas professoras pedagogas: uma era estudante de doutorado da Faculdade de Educação da UFMG e a outra é professora da Prefeitura Municipal de Belo Horizonte. A partir dos desenhos e textos produzidos pelos estudantes, a pesquisadora desenvolveu algumas categorias que foram apresentadas para as duas professoras separadamente. Cada professora emitiu sua opinião para ajustar as categorias. Os ajustes foram feitos até que chegou-se ao consenso entre as opiniões das duas professoras e da pesquisadora. Esse consenso resultou nas categorias apresentadas neste trabalho.

\section{REFERÊNCIAS}

BARTHES, R. (1964). Rhétorique de l'image. Communication, 4, Paris: Seuil, 1964. Para esta pesquisa, utilizamos a versão traduzida deste artigo reunida no livro O óbvio e o obtuso: ensaios críticos III, publicado pela editora Nova Fronteira, no Rio de Janeiro, em 1990. Título original: L'obvieetl'obtus - Essais critiques III,EditionsduSeuil, Paris, 1982.

CARVALHO, A.M. P.; BARBOSA-LIMA, M.C. O desenho infantil como instrumento de avaliação da construção do conhecimento físico. Revista Electrónica de Enseñanza de lãs Ciencias, v. 7, n. 2, p. 337-348, 2008.

COUTINHO, F. A. et al. Análise do valor didático de imagens presentes em livros de Biologia para o ensino médio. Revista Brasileira de Pesquisa em Educação em Ciências, São Paulo, v. 10, n. 3, 2010.

FERREIRA, S. Imaginação e linguagem no desenho da criança. Campinas, SP: Papirus, 1998.

HALLIDAY, M. A. K. Estrutura e função da linguagem. In: LYONS, J. (Org.) Novos

horizontes em linguística.Tradução de Jesus Antônio Durigan. São Paulo: Cultrix, 1976. p. 134-160.

HALLIDAY, M. A. K. An introduction to Functional Grammar. London: Edward Arnold, 1985.

IAVELBERG, R. O desenho cultivado da criança: prática e formação de educadores. 2. ed. Porto Alegre, RS: Zouk, 2008.

KRESS, G.; VAN LEEUWEN, T. Reading images: the grammar of visual design. London: Routledge, 1996.

KRESS, G.; OGBORN, J.; MARTINS, I. A sattelite view of language: Some lessons from science classrooms. Language Awareness, v. 7, n. 2, p. 69-89, 1998.

KRESS, G.;VANL EEUWEN, T. Multimodal Discourse: the modes and media of contemporany communication. London: Arnold, 2001.

KRESS, G. et al. Multimodalteaching and learning: the rhetorics of the science classroom. London: Continuum, 2001.

KRESS, G.; BEZEMER, J. Escribir em um mundo de representación multimodal. In: KALMAN, J:; STREET, B. V. (Coord.) Lectura, escritura y matemáticas como prácticas sociales: diálogos con América Latina. México: Siglo XXI, 2009. p. 64-83. 
LEMKE, J.L.Talking science: language, learning and values. Norwood, NJ: Ablex Publish Corporation, 1990. MARTINS, I.; GOUVÊA, G. Analisando aspectos da leitura de imagens em livros didáticos de ciências por estudantes do ensino fundamental no Brasil. Enseñanza de lãs Ciencias, v. extra, p. 1-3, 2005.

MARTINS, I.; GOUVÊA, G.; PICCINI, C. Aprendendo com imagens. Ciência e Cultura-Temas e Debates, São Paulo, v. 57, n. 4, p. 38-40, 2005.

MUSSALIM, F. Análise do Discurso. In: MUSSALIM, F; BENTES, A. C. (Org). Introducão à Linguística. domínios e fronteiras. v. 2. São Paulo: Cortez, 2001.

PRALON, L. H. As imagens da saúde em liuros didáticos de ciências. 2011. Número de folhas. Tese (Doutorado em Educação em Ciências e Saúde) - Núcleo de Tecnologia Educacional para a Saúde, Universidade Federal do Rio de Janeiro, Rio de Janeiro, 2011.

SCHWARZ, M. L;; SEVEGNANI, L.; ANDRÉ, P. Representações da Mata Atlântica e de sua biodiversidade por meio dos desenhos infantis. Ciênc. educ., Bauru, v.13, n.3, p. 369-388, 2007.

SOUZA, L. H. P.; GOUVÊA, G. Imagens da saúde no livro didático de ciências. In: VII ENPEC, Florianópolis, nov. 2009. Anais... Florianópolis, 2009.

VYGOTSKY, L. S. La imaginación y el arte en la infancia: ensayo psicologico. Madrid: EdicionesAkal S.A, 2003.

VYGOTSKY, L. S. Formação social da mente: o desenvolvimento dos processos psicológicos superiores. São Paulo, São Paulo: Martins Fontes, 2007.

Data recebimento: 30/03/2015

Data aprovaçãa: 15/09/2015

Data da versão final: 13/10/2015

Contato:

Andreza Fortinida Silva

Gerais, Faculdade de Educação - Av. Antônio Carlos, 6627

Bairro Pampulha - Belo Horizonte/MG, - Brasil

CEP 31270-901 